\title{
Streamflow Statistics for the Narraguagus River at Cherryfield, Maine
}

By Robert W. Dudley and Joseph P. Nielsen

U.S. GEOLOGICAL SURVEY

Open-File Report 00-95

Prepared in cooperation with the

MAINE STATE PLANNING OFFICE 


\section{U.S. DEPARTMENT OF THE INTERIOR \\ BRUCE BABBITT, Secretary}

U.S. GEOLOGICAL SURVEY

Charles G. Groat, Director

The use of firm, trade, and brand names in this report is for identification purposes

only and does not constitute endorsement by the U.S. Geological Survey.

For additional information write to:

\author{
District Chief \\ U.S. Geological Survey \\ 26 Ganneston Drive \\ Augusta, ME 04330
}

Copies of this report can be purchased from:

\author{
U.S. Geological Survey \\ Information Services \\ Box 25286 \\ Federal Center \\ Denver, CO 80225
}




\section{CONTENTS}

Abstract

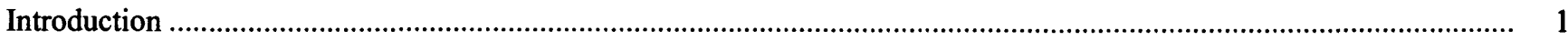

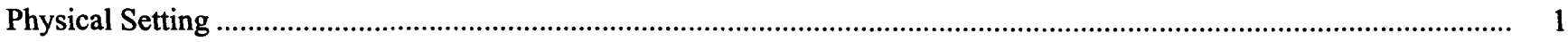

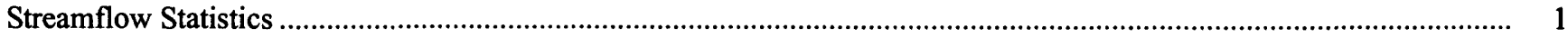

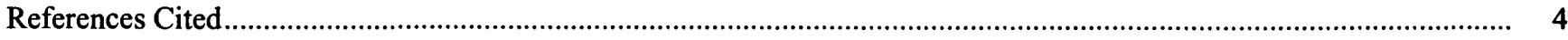

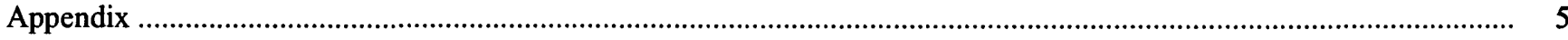

\section{FIGURES}

1. Map showing study area and location of the streamgaging station used in the analysis..................................... 2

2. Graph showing monthly median streamflows for the Narraguagus River at Cherryfield, Maine, using the period of record, 1948-92.

3-14. Graphs showing monthly flow-duration curves and monthly flow-duration statistics based on period of record, March 1948 through December 1992, for the Narraguagus River at Cherryfield, Maine.

15. Graph showing a flow-duration curve and flow-duration statistics based on period of record, March 1948 through December 1992, for the Narraguagus River at Cherryfield, Maine

\section{TABLE}

1. Streamflow statistics for the Narraguagus River at Cherryfield, Maine for the period 1948-92.

\section{CONVERSION FACTORS}

\begin{tabular}{rll}
\hline Multiply & By & To obtain \\
\hline cubic foot per second $\left(\mathrm{ft}^{3} / \mathrm{s}\right)$ & 0.02832 & cubic meter per second \\
foot $(\mathrm{ft})$ & 0.3048 & meter \\
inch (in.) & 25.4 & millimeter \\
inch per year (in/yr) & 25.4 & millimeter per year \\
mile (mi) & 1.609 & kilometer \\
square mile $\left(\mathrm{mi}^{2}\right)$ & 2.59 & square kilometer \\
\hline
\end{tabular}

To convert temperature in degrees Fahrenheit $\left({ }^{\circ} \mathrm{F}\right)$ to degrees Celcius $\left({ }^{\circ} \mathrm{C}\right)$, use the following equation:

$$
{ }^{\circ} \mathrm{F}=\left(1.8 \times{ }^{\circ} \mathrm{C}\right)+32
$$




\title{
Streamflow Statistics for the Narraguagus River at Cherryfield, Maine
}

\author{
by Robert W. Dudley and Joseph P. Nielsen
}

\section{ABSTRACT}

Streamflow data have been collected for the Narraguagus River from 1948 to the present (2000) at the U.S. Geological Survey (USGS) streamgaging station at Cherryfield, Maine. This report describes a study done by the USGS to determine streamflow statistics using the streamflow record at the Narraguagus River station for use in total water use management plans implemented by State and Federal agencies. Because the effect of changes in irrigation practices from 1993 to the present on streamflow in the Narraguagus basin is unknown and potentially significant, streamflow data after December 1992 were not used in the determination of the streamflow statistics. For the period 194892 , monthly median streamflows range from $93.0 \mathrm{ft}^{3} / \mathrm{s}$ (August) to $1,000 \mathrm{ft}^{3} / \mathrm{s}$ (April). The median streamflow for the selected period of record for all days (1948-92) is $302 \mathrm{ft}^{3} / \mathrm{s}$.

\section{INTRODUCTION}

In 1997, the State of Maine developed a conservation plan for Atlantic salmon in seven rivers in Maine (Maine Atlantic Salmon Task Force, 1997). As part of its implementation, the plan called for the development of total water use management plans for each of the river basins.

The only source of long-term hydrologic data in the Narraguagus River basin on which to base water use management plans is a U.S. Geological Survey (USGS) stream-gaging station on the Narraguagus River at Cherryfield (station 01022500), which has been operated since March 1948. As of the writing of this report, this gaging station is in operation.

This report describes a study done by the USGS to determine streamflow statistics using the streamflow record at the Narraguagus River station.

\section{PHYSICAL SETTING}

The Narraguagus River basin is in eastern Maine along the coast of the Atlantic Ocean (figure 1). Draining an area of $227 \mathrm{mi}^{2}$, the river flows predominately from north to south beginning at Eagle Lake (elevation $406 \mathrm{ft}$ ) in the civil division T34 MD. The basin is bounded to the east by the Pleasant and Machias River basins and to the west by the Union River basin. Largely unsettled, the basin is made up primarily of forest, blueberry barrens, lakes, ponds, and heath. The average annual temperature is $42^{\circ} \mathrm{F}$ and ranges from an average of $18^{\circ} \mathrm{F}$ in January to $64^{\circ} \mathrm{F}$ in July (U.S. Department of Commerce, National Oceanic and Atmospheric Administration, 1996). The average annual precipitation is 49 in. and is fairly evenly distributed throughout the year.

Monthly median streamflows in the Narraguagus River, as recorded by the USGS streamgaging station at Cherryfield, show a seasonal distribution common in Maine (figure 2). High flows typically occur in early spring and late fall, and low flows generally occur in the summer and early fall.

\section{STREAMFLOW STATISTICS}

Various streamflow statistics were computed for the Narraguagus River at Cherryfield using daily mean flow data. Median, mean, harmonic mean, and geometric mean flows (table 1) were computed for each month and for the period of record using methods defined in Helsel and Hirsch (1992). In addition, flow-duration curves and selected duration statistics were computed for each month and for the entire selected record. A flow-duration curve indicates the amount of time, in percent, that a given streamflow is equaled or exceeded for the time period in question. For example, the 


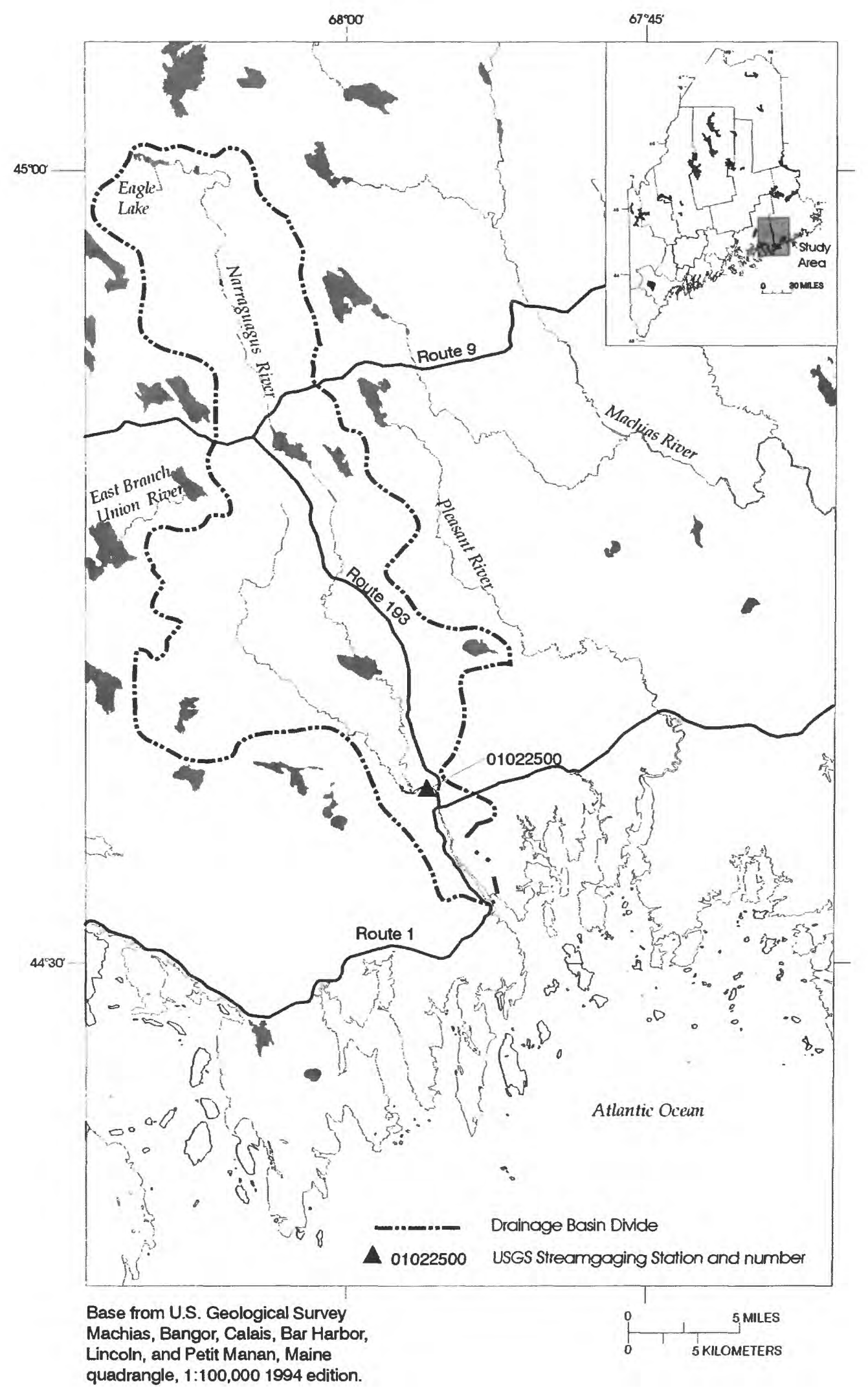

Figure 1. Study area and location of the USGS streamgaging station at Cherryfield. Maine. 


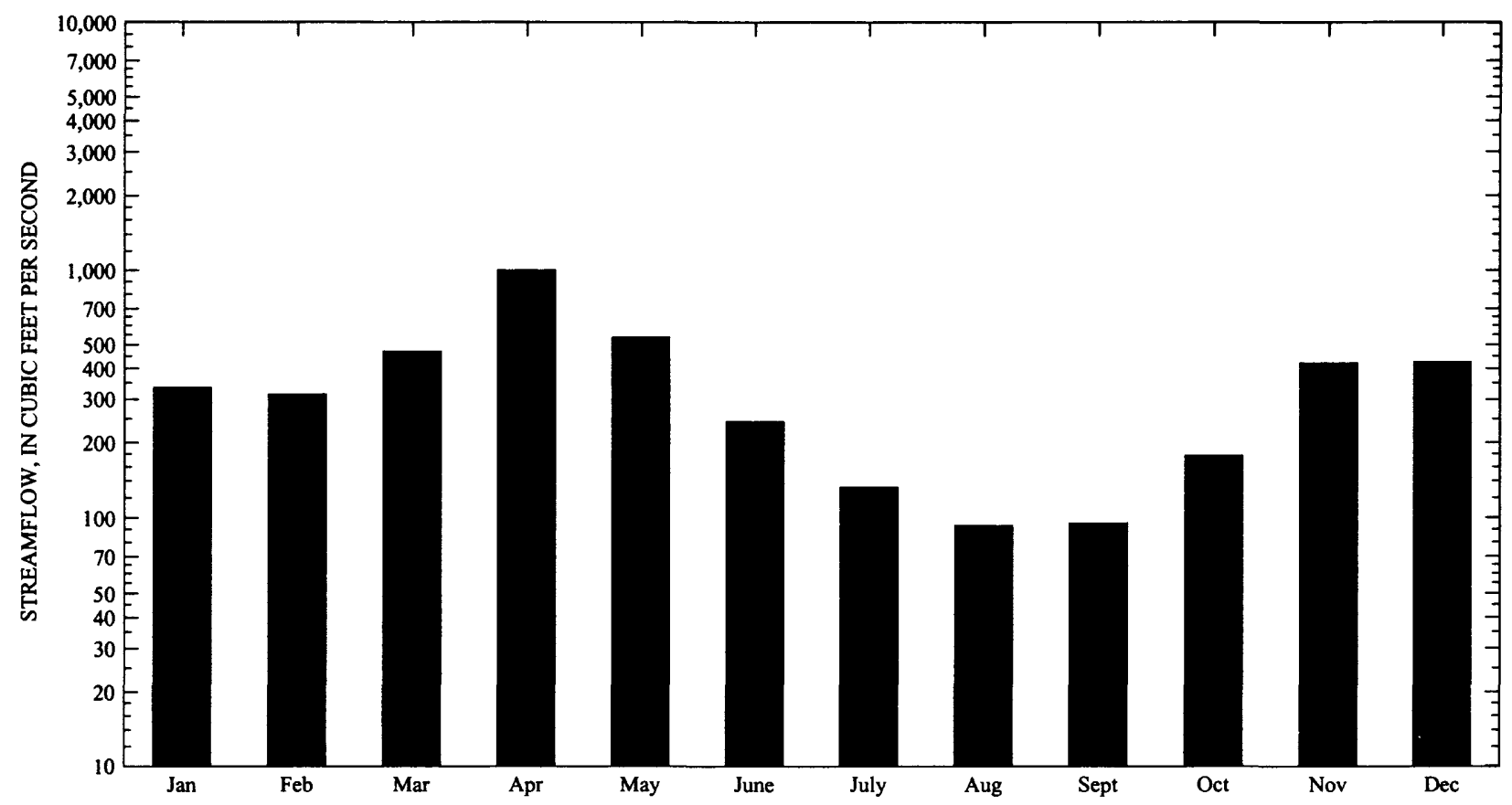

Figure 2. Median streamflows for the Narraguagus River at Cherryfield, Maine for the period 1948-92.

Table 1. Streamflow statistics for the Narraguagus River at Cherryfield, Maine for the period 1948-92

\begin{tabular}{lcccc}
\hline Period & $\begin{array}{c}\text { Median streamflow in } \\
\text { cubic feet per second }\end{array}$ & $\begin{array}{c}\text { Mean streamflow in cubic } \\
\text { feet per second }\end{array}$ & $\begin{array}{c}\text { Harmonic mean } \\
\text { streamflow in cubic feet } \\
\text { per second }\end{array}$ & $\begin{array}{c}\text { Geometric mean } \\
\text { streamflow in cubic feet } \\
\text { per second }\end{array}$ \\
\hline January & 335 & 497 & 287 & 366 \\
February & 315 & 473 & 273 & 350 \\
March & 470 & 705 & 384 & 508 \\
April & 1000 & 1220 & 924 & 1052 \\
May & 534 & 693 & 484 & 563 \\
June & 244 & 344 & 221 & 268 \\
July & 132 & 187 & 117 & 142 \\
August & 93.0 & 142 & 83.5 & 105 \\
September & 95.0 & 172 & 78.4 & 106 \\
October & 177 & 279 & 125 & 182 \\
November & 422 & 589 & 280 & 406 \\
December & 426 & 644 & 353 & 464 \\
Entire selected & 302 & 494 & 184 & 300 \\
record & & & & \\
\hline
\end{tabular}


August flow duration curve illustrates the amount of time that various flows are equaled or exceeded for all recorded streamflows occurring in the month of August during the selected period of record. Likewise, the flow-duration curve for the entire selected period of record is computed using all recorded streamflows for all days of the year.

Effects on streamflow of the Narraguagus River due to agriculture (irrigation), sylvaculture, impoundments, and other land uses were not investigated in detail due to a lack of historical information about these practices in the basin. It is known, however, that irrigation for blueberry growing has been practiced in the Narraguagus basin since the 1950's. An effort was made to obtain the longest period of streamflow record available that was not significantly affected by irrigation withdrawal with which to determine streamflow statistics. Streamflow statistics determined using streamflow record significantly affected by withdrawal (particularly during the summer months) could bias water management guidelines set by State and Federal agencies.

Historical withdrawal information provided by blueberry growers operating in the Narraguagus basin, while insufficient to perform a detailed statistical analysis of the effects on streamflow in the Narraguagus
River, provides a basis for choosing an appropriate period of record for computing streamflow statistics. Qualitative evaluation of these data imply that the impact of withdrawal prior to 1993 could be considered minor for purposes of computing streamflow statistics for this report. Because the effect of changes in irrigation practices from 1993 to the present on the streamflow is unknown and potentially significant, streamflow data after 1992 were not used in the determination of streamflow statistics in this report.

Monthly flow-duration curves and selected flowduration statistics for the period 1948-92 are shown in the graphs and tables in Figures 3-14 in the appendix of this report. A similar curve and statistics for the entire selected record are shown in Figure 15.

\section{REFERENCES CITED}

Helsel, D.R., and Hirsch, R.M., 1992, Statistical methods in water resources: Amsterdam, the Netherlands, Elsevier Science Publishers, $522 \mathrm{p}$.

Maine Atlantic Salmon Task Force, 1997, Atlantic salmon conservation plan for seven Maine rivers, $393 \mathrm{p}$.

U.S. Department of Commerce, National Oceanic and Atmospheric Administration, 1996, Climatological data, annual summary, New England, v. 108, no. 13, 35 p. 


\section{APPENDIX}

Figures 3-15: Flow-Duration Curves and Statistics 


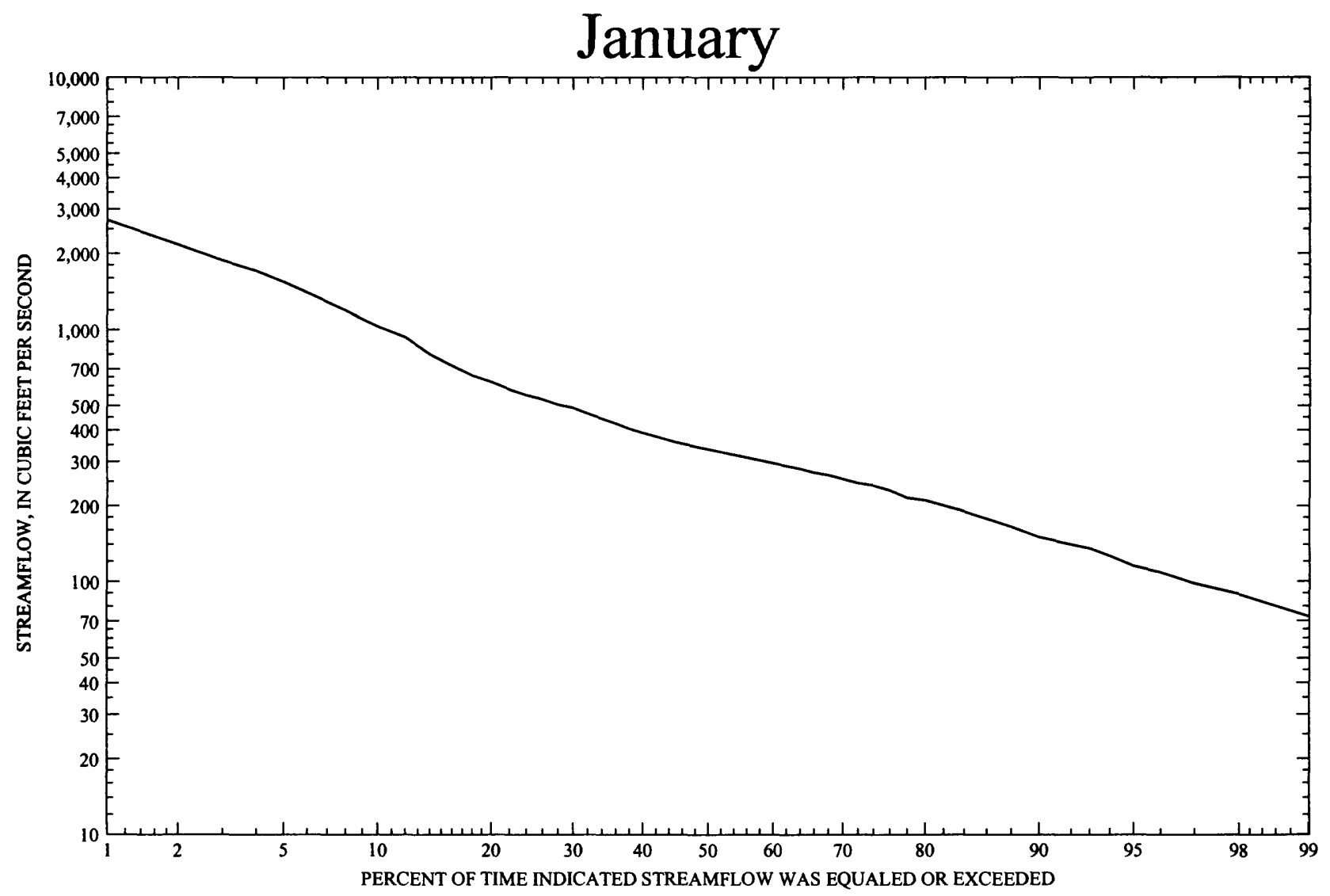

\begin{tabular}{cccc}
\hline $\begin{array}{c}\text { Percent of time } \\
\text { indicated } \\
\text { streamflow was } \\
\text { equaled or } \\
\text { exceeded }\end{array}$ & $\begin{array}{c}\text { Streamflow, in } \\
\text { cubic feet per } \\
\text { second }\end{array}$ & $\begin{array}{c}\text { Percent of time } \\
\text { indicated } \\
\text { streamflow was } \\
\text { equaled or } \\
\text { exceeded }\end{array}$ & $\begin{array}{c}\text { Streamflow, in } \\
\text { cubic foet per } \\
\text { second }\end{array}$ \\
\hline 1 & 2700 & 55 & 315 \\
5 & 1540 & 60 & 295 \\
10 & 1030 & 65 & 275 \\
15 & 760 & 70 & 255 \\
20 & 620 & 75 & 235 \\
25 & 540 & 80 & 210 \\
30 & 490 & 85 & 184 \\
35 & 435 & 90 & 150 \\
40 & 390 & 95 & 115 \\
45 & 357 & 99 & 73 \\
50 & 335 & & \\
\hline
\end{tabular}

Figure 3. Flow-duration curve and flow-duration statistics for January based on historical period of record, March 1948 through December 1992, for Narraguagus River at Cherryfield, Maine. 


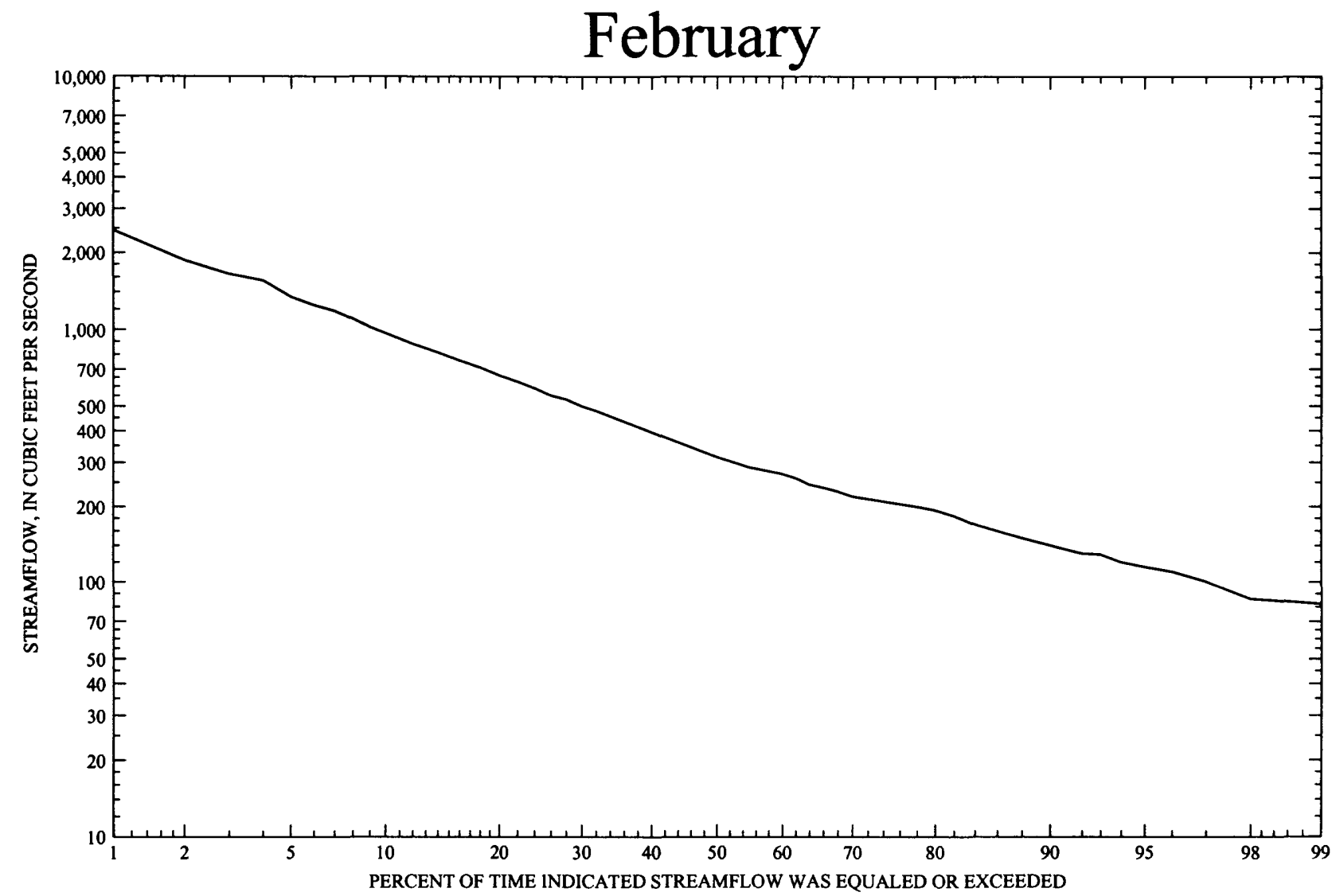

\begin{tabular}{cccc}
\hline $\begin{array}{c}\text { Percent of time } \\
\text { indicated } \\
\text { streamflow was } \\
\text { equaled or } \\
\text { exceeded }\end{array}$ & $\begin{array}{c}\text { Streamflow, in } \\
\text { cubic feet per } \\
\text { second }\end{array}$ & $\begin{array}{c}\text { Percent of time } \\
\text { indicated } \\
\text { streamflow was } \\
\text { equaled or } \\
\text { exceeded }\end{array}$ & $\begin{array}{c}\text { Streamflow, in } \\
\text { cubic feet per } \\
\text { second }\end{array}$ \\
\hline 1 & 2450 & 55 & 287 \\
5 & 1340 & 60 & 270 \\
10 & 967 & 65 & 241 \\
15 & 784 & 70 & 220 \\
20 & 660 & 75 & 208 \\
25 & 570 & 80 & 194 \\
30 & 500 & 85 & 165 \\
35 & 446 & 90 & 140 \\
40 & 395 & 95 & 115 \\
45 & 353 & 99 & 82 \\
50 & 315 & & \\
\hline
\end{tabular}

Figure 4. Flow-duration curve and flow-duration statistics for February based on historical period of record, March 1948 through December 1992, for Narraguagus River at Cherryfield, Maine. 
March

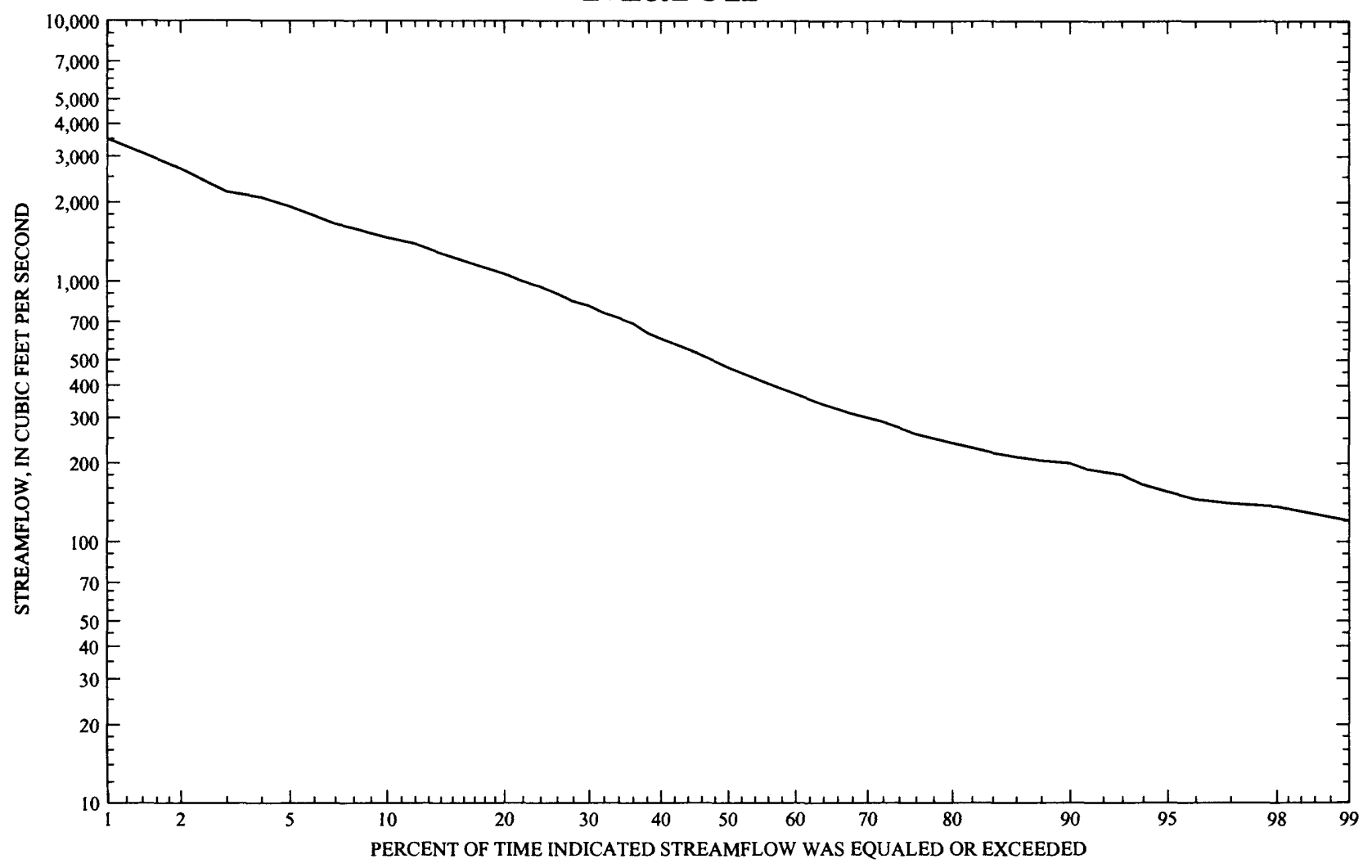

\begin{tabular}{cccc}
\hline $\begin{array}{c}\text { Percent of time } \\
\text { indicated } \\
\text { streamflow was } \\
\text { equaled or } \\
\text { exceeded }\end{array}$ & $\begin{array}{c}\text { Streamflow, in } \\
\text { cubic feet per } \\
\text { second }\end{array}$ & $\begin{array}{c}\text { Percent of time } \\
\text { indicated } \\
\text { streamflow was } \\
\text { equaled or } \\
\text { exceeded }\end{array}$ & $\begin{array}{c}\text { Streamflow, in } \\
\text { cubic feet per } \\
\text { second }\end{array}$ \\
\hline 1 & 3490 & 55 & 416 \\
5 & 1930 & 60 & 371 \\
10 & 1470 & 65 & 332 \\
15 & 1240 & 70 & 300 \\
20 & 1070 & 75 & 268 \\
25 & 926 & 80 & 239 \\
30 & 805 & 85 & 216 \\
35 & 707 & 90 & 200 \\
40 & 605 & 95 & 155 \\
45 & 538 & 99 & 120 \\
50 & 470 & & \\
\hline
\end{tabular}

Figure 5. Flow-duration curve and flow-duration statistics for March based on historical period of record, March 1948 through December 1992, for Narraguagus River at Cherryfield, Maine. 


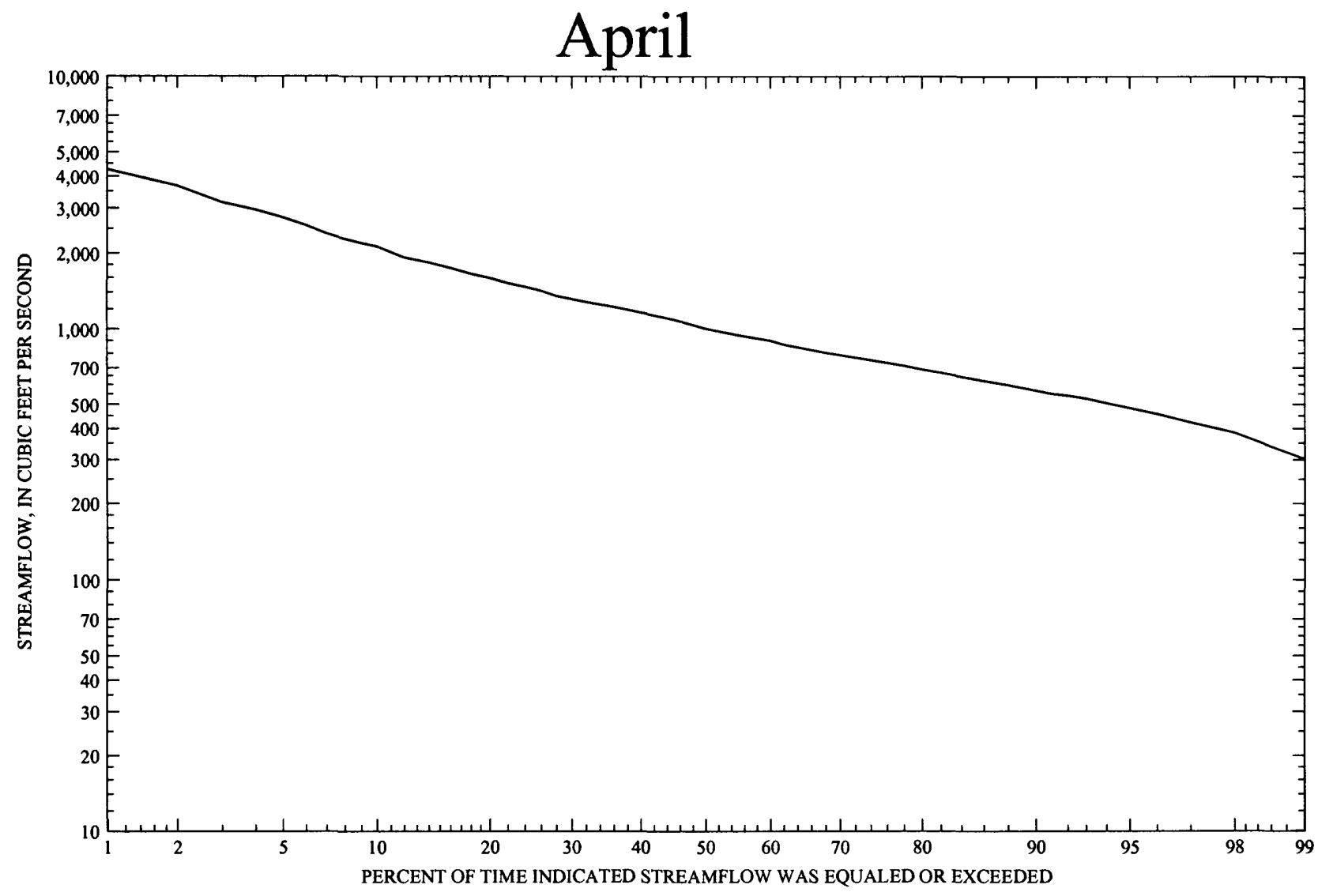

\begin{tabular}{cccc}
\hline $\begin{array}{c}\text { Percent of time } \\
\text { indicated } \\
\text { streamflow was } \\
\text { equaled or } \\
\text { exceeded }\end{array}$ & $\begin{array}{c}\text { Streamflow, in } \\
\text { cubic feet per } \\
\text { second }\end{array}$ & $\begin{array}{c}\text { Percent of time } \\
\text { indicated } \\
\text { streamflow was } \\
\text { equaled or } \\
\text { exceeded }\end{array}$ & $\begin{array}{c}\text { Streamflow, in } \\
\text { cubic feet per } \\
\text { second }\end{array}$ \\
\hline 1 & 4250 & 55 & 945 \\
5 & 2750 & 60 & 896 \\
10 & 2120 & 65 & 835 \\
15 & 1780 & 70 & 786 \\
20 & 1590 & 75 & 740 \\
25 & 1440 & 80 & 689 \\
30 & 1310 & 85 & 632 \\
35 & 1240 & 90 & 566 \\
40 & 1160 & 95 & 484 \\
45 & 1090 & 99 & 301 \\
50 & 1000 & & \\
\hline
\end{tabular}

Figure 6. Flow-duration curve and flow-duration statistics for April based on historical period of record, March 1948 through December 1992, for Narraguagus River at Cherryfield, Maine. 


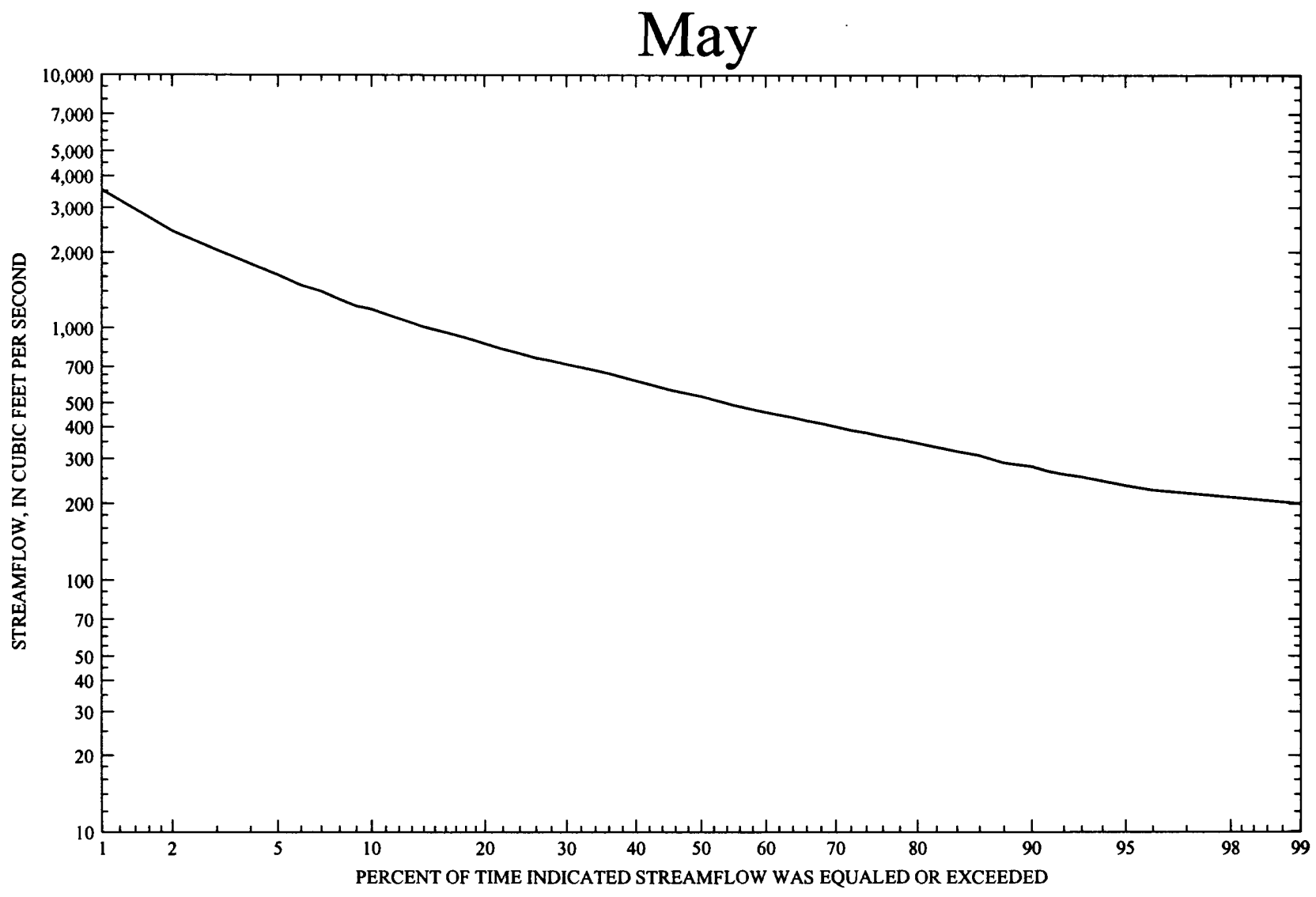

\begin{tabular}{cccc}
\hline $\begin{array}{c}\text { Percent of time } \\
\text { indicated } \\
\text { streamflow was } \\
\text { equaled or } \\
\text { exceeded }\end{array}$ & $\begin{array}{c}\text { Streamflow, in } \\
\text { cubic feet per } \\
\text { second }\end{array}$ & $\begin{array}{c}\text { Percent of time } \\
\text { indicated } \\
\text { streamflow was } \\
\text { equaled or } \\
\text { exceeded }\end{array}$ & $\begin{array}{c}\text { Streamflow, in } \\
\text { cubic feet per } \\
\text { second }\end{array}$ \\
\hline 1 & 3510 & 55 & 492 \\
5 & 1630 & 60 & 460 \\
10 & 1190 & 65 & 432 \\
15 & 986 & 70 & 402 \\
20 & 868 & 75 & 374 \\
25 & 775 & 80 & 347 \\
30 & 716 & 85 & 316 \\
35 & 667 & 90 & 280 \\
40 & 617 & 95 & 236 \\
45 & 568 & 99 & 200 \\
50 & 534 & & \\
\hline
\end{tabular}

Figure 7. Flow-duration curve and flow-duration statistics for May based on historical period of record, March 1948 through December 1992, for Narraguagus River at Cherryfield, Maine. 


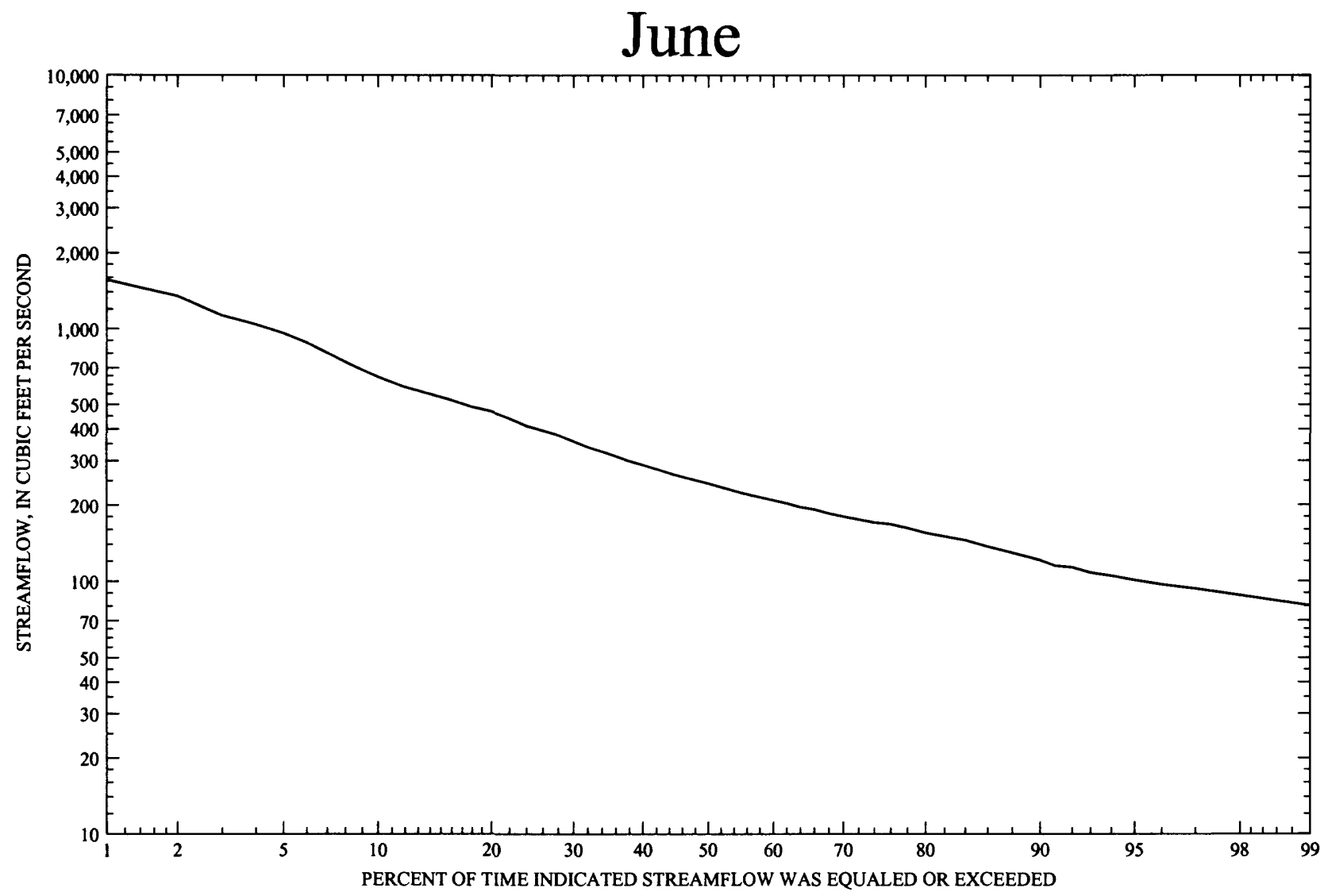

\begin{tabular}{cccc}
\hline $\begin{array}{c}\text { Percent of time } \\
\text { indicated } \\
\text { streamflow was } \\
\text { equaled or } \\
\text { exceeded }\end{array}$ & $\begin{array}{c}\text { Streamflow, in } \\
\text { cubic feet per } \\
\text { second }\end{array}$ & $\begin{array}{c}\text { Percent of time } \\
\text { indicated } \\
\text { streamflow was } \\
\text { equaled or } \\
\text { exceeded }\end{array}$ & $\begin{array}{c}\text { Streamflow, in } \\
\text { cubic feet per } \\
\text { second }\end{array}$ \\
\hline 1 & 1560 & 55 & 224 \\
5 & 960 & 60 & 209 \\
10 & 643 & 65 & 194 \\
15 & 534 & 70 & 180 \\
20 & 468 & 75 & 169 \\
25 & 403 & 80 & 155 \\
30 & 358 & 85 & 141 \\
35 & 319 & 90 & 121 \\
40 & 289 & 95 & 101 \\
45 & 263 & 99 & 80 \\
50 & 244 & & \\
\hline
\end{tabular}

Figure 8. Flow-duration curve and flow-duration statistics for June based on historical period of record, March 1948 through December 1992, for Narraguagus River at Cherryfield, Maine. 


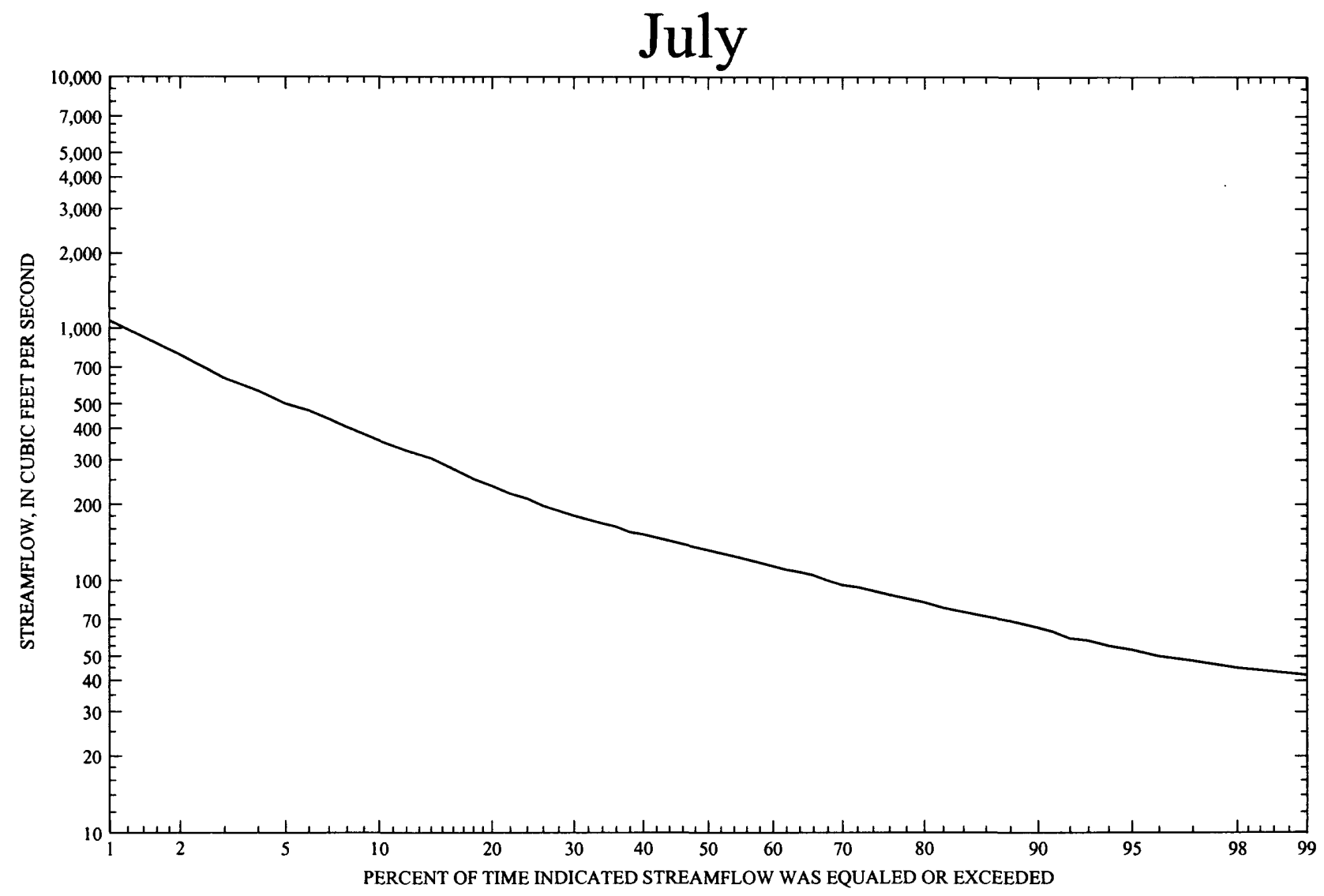

\begin{tabular}{cccc}
\hline $\begin{array}{c}\text { Percent of time } \\
\text { indicated } \\
\text { streamflow was } \\
\text { equaled or } \\
\text { exceeded }\end{array}$ & $\begin{array}{c}\text { Streamflow, in } \\
\text { cubic feet per } \\
\text { second }\end{array}$ & $\begin{array}{c}\text { Percent of time } \\
\text { indicated } \\
\text { streamflow was } \\
\text { equaled or } \\
\text { exceeded }\end{array}$ & $\begin{array}{c}\text { Streamflow, in } \\
\text { cubic feet per } \\
\text { second }\end{array}$ \\
\hline 1 & 1070 & 55 & 123 \\
5 & 501 & 60 & 114 \\
10 & 357 & 65 & 106 \\
15 & 290 & 70 & 96 \\
20 & 236 & 75 & 90 \\
25 & 204 & 80 & 82 \\
30 & 180 & 85 & 74 \\
35 & 166 & 90 & 65 \\
40 & 152 & 95 & 53 \\
45 & 142 & 99 & 42 \\
50 & 132 & & \\
\hline
\end{tabular}

Figure 9. Flow-duration curve and flow-duration statistics for July based on historical period of record, March 1948 through December 1992, for Narraguagus River at Cherryfield, Maine. 


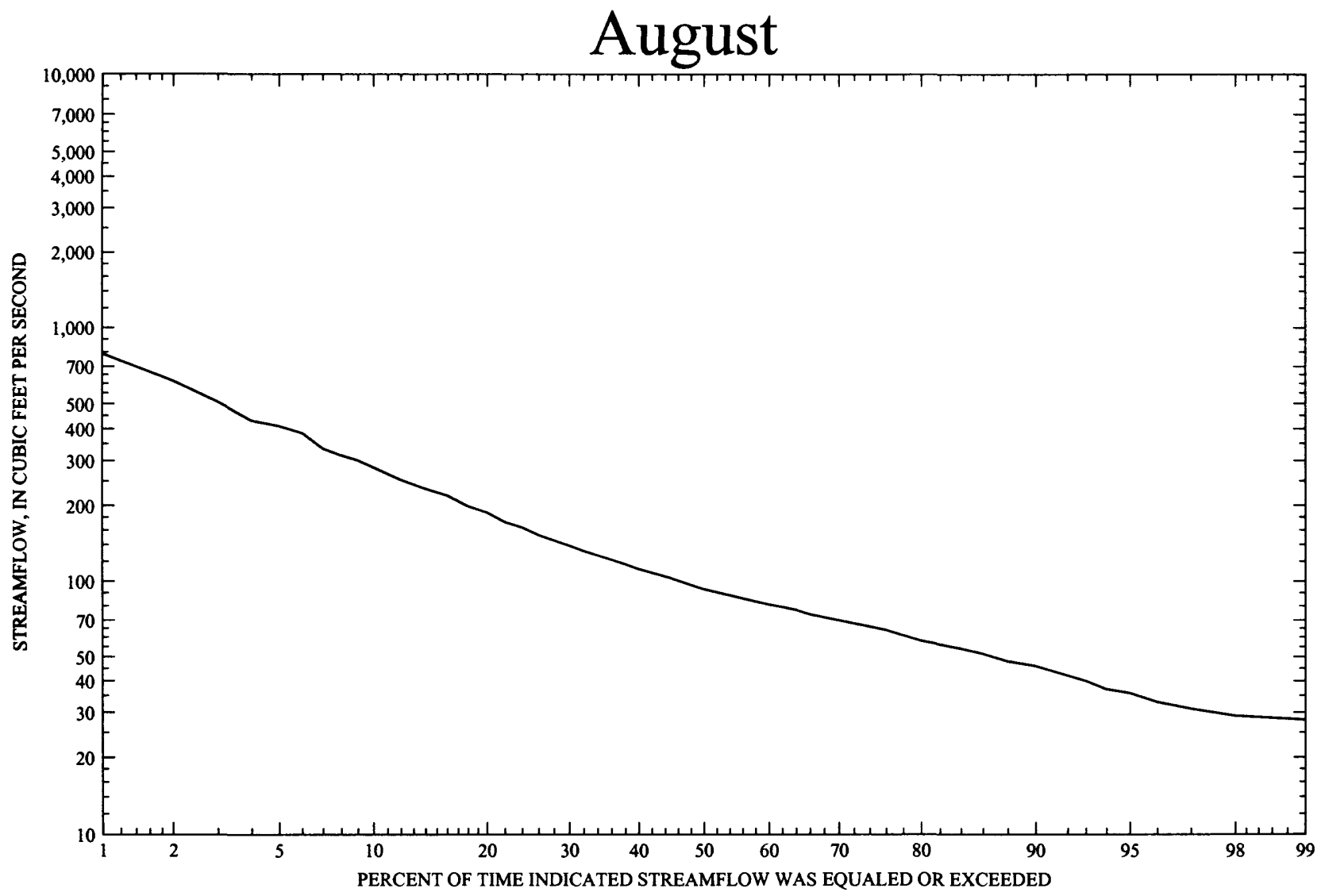

\begin{tabular}{cccc}
\hline $\begin{array}{c}\text { Percent of time } \\
\text { indicated } \\
\text { streamflow was } \\
\text { equaled or } \\
\text { exceeded }\end{array}$ & $\begin{array}{c}\text { Streamflow, in } \\
\text { cubic feet per } \\
\text { second }\end{array}$ & $\begin{array}{c}\text { Percent of time } \\
\text { indicated } \\
\text { streamflow was } \\
\text { equaled or } \\
\text { exceeded }\end{array}$ & $\begin{array}{c}\text { Streamflow, in } \\
\text { cubic feet per } \\
\text { second }\end{array}$ \\
\hline 1 & 787 & 55 & 87 \\
5 & 409 & 60 & 81 \\
10 & 283 & 65 & 76 \\
15 & 226 & 70 & 70 \\
20 & 188 & 75 & 65 \\
25 & 158 & 80 & 58 \\
30 & 139 & 85 & 53 \\
35 & 124 & 90 & 46 \\
40 & 112 & 95 & 36 \\
45 & 103 & 99 & 28 \\
50 & 93 & & \\
\hline
\end{tabular}

Figure 10. Flow-duration curve and flow-duration statistics for August based on historical period of record, March 1948 through December 1992, for Narraguagus River at Cherryfield, Maine. 


\section{September}

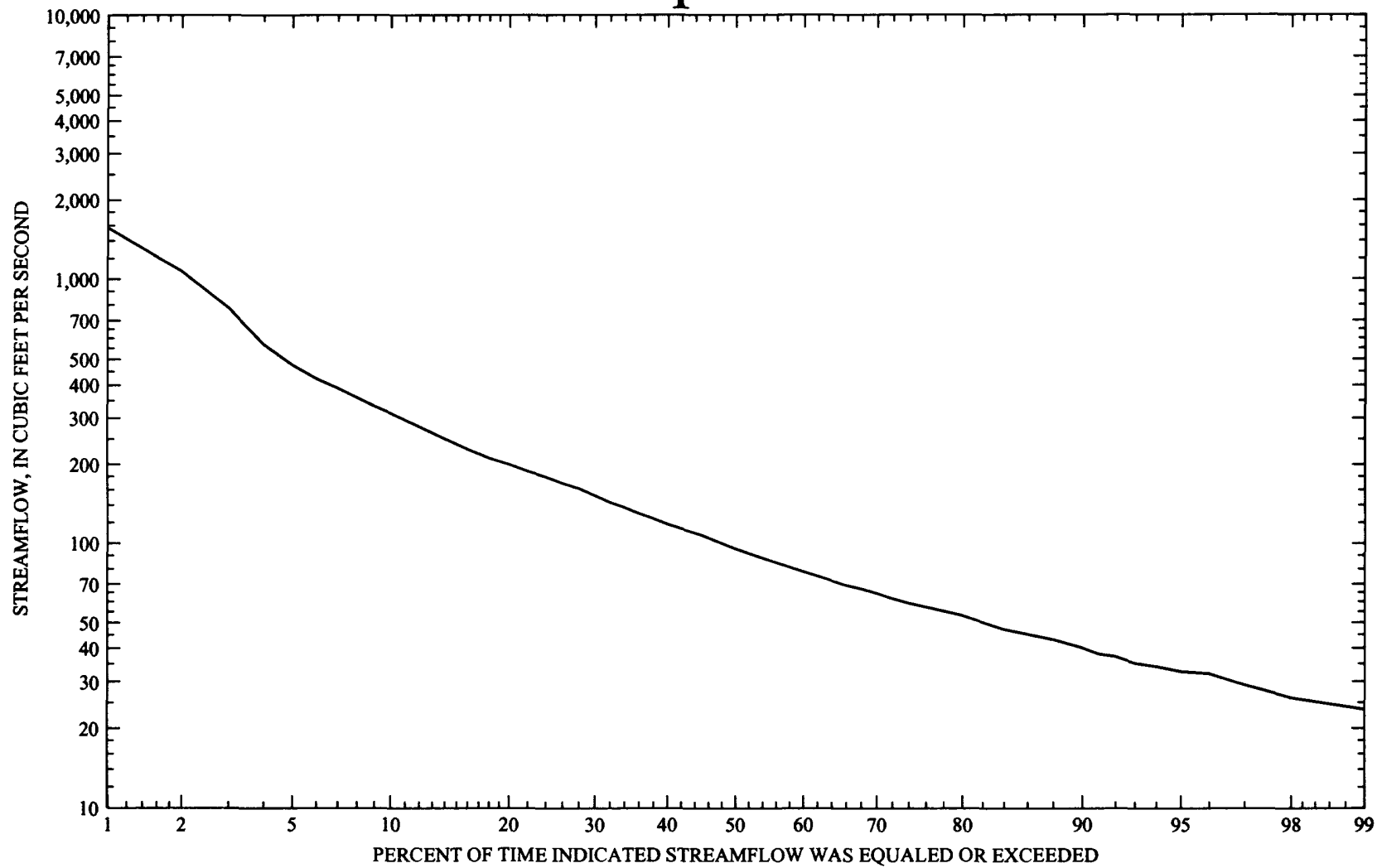

\begin{tabular}{cccc}
\hline $\begin{array}{c}\text { Percent of time } \\
\text { indicated } \\
\text { streamflow was } \\
\text { equaled or } \\
\text { exceeded }\end{array}$ & $\begin{array}{c}\text { Streamflow, in } \\
\text { cubic feet per } \\
\text { second }\end{array}$ & $\begin{array}{c}\text { Percent of time } \\
\text { indicated } \\
\text { streamflow was } \\
\text { equaled or } \\
\text { exceeded }\end{array}$ & $\begin{array}{c}\text { Streamflow, in } \\
\text { cubic foet per } \\
\text { second }\end{array}$ \\
\hline 1 & 1560 & 55 & 86 \\
5 & 475 & 60 & 78 \\
10 & 313 & 65 & 70 \\
15 & 239 & 70 & 64 \\
20 & 200 & 75 & 58 \\
25 & 174 & 80 & 53 \\
30 & 152 & 85 & 46 \\
35 & 133 & 90 & 40 \\
40 & 118 & 95 & 33 \\
45 & 107 & 99 & 24 \\
50 & 95 & & \\
\hline
\end{tabular}

Figure 11. Flow-duration curve and flow-duration statistics for September based on historical period of record, March 1948 through December 1992, for Narraguagus River at Cherryfield, Maine. 


\section{October}

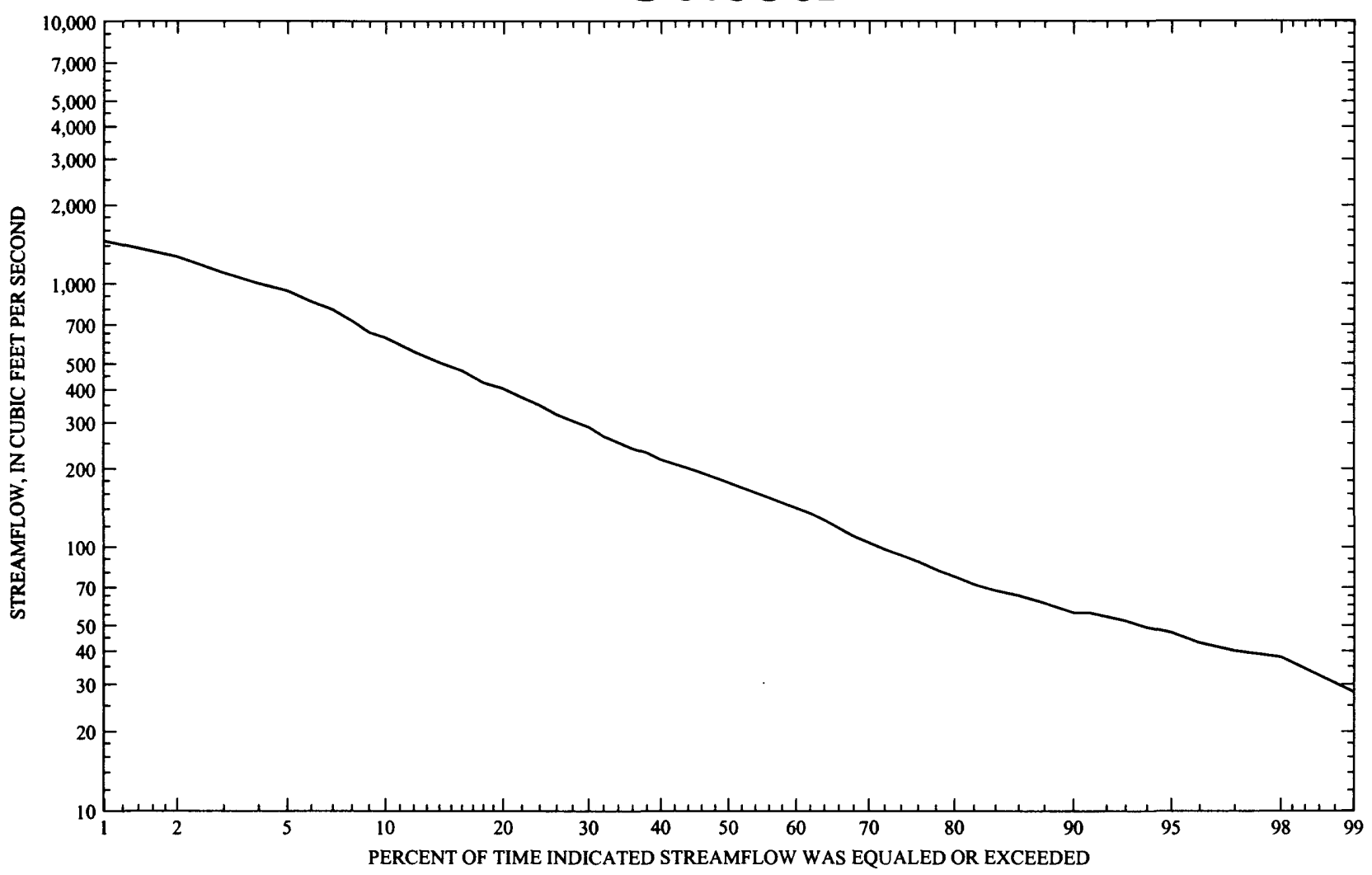

\begin{tabular}{cccc}
\hline $\begin{array}{c}\text { Percent of time } \\
\text { indicated } \\
\text { streamflow was } \\
\text { equaled or } \\
\text { exceeded }\end{array}$ & $\begin{array}{c}\text { Streamflow, in } \\
\text { cubic feet per } \\
\text { second }\end{array}$ & $\begin{array}{c}\text { Percent of time } \\
\text { indicated } \\
\text { streamflow was } \\
\text { equaled or } \\
\text { exceeded }\end{array}$ & $\begin{array}{c}\text { Streamflow, in } \\
\text { cubic feet per } \\
\text { second }\end{array}$ \\
\hline 1 & 1460 & 55 & 158 \\
5 & 939 & 60 & 141 \\
10 & 625 & 65 & 122 \\
15 & 488 & 70 & 104 \\
20 & 404 & 75 & 90 \\
25 & 336 & 80 & 77 \\
30 & 289 & 85 & 66 \\
35 & 245 & 90 & 56 \\
40 & 217 & 95 & 47 \\
45 & 197 & 99 & 28 \\
50 & 177 & & \\
\hline
\end{tabular}

Figure 12. Flow-duration curve and flow-duration statistics for October based on historical period of record, March 1948 through December 1992, for Narraguagus River at Cherryfield, Maine. 
November

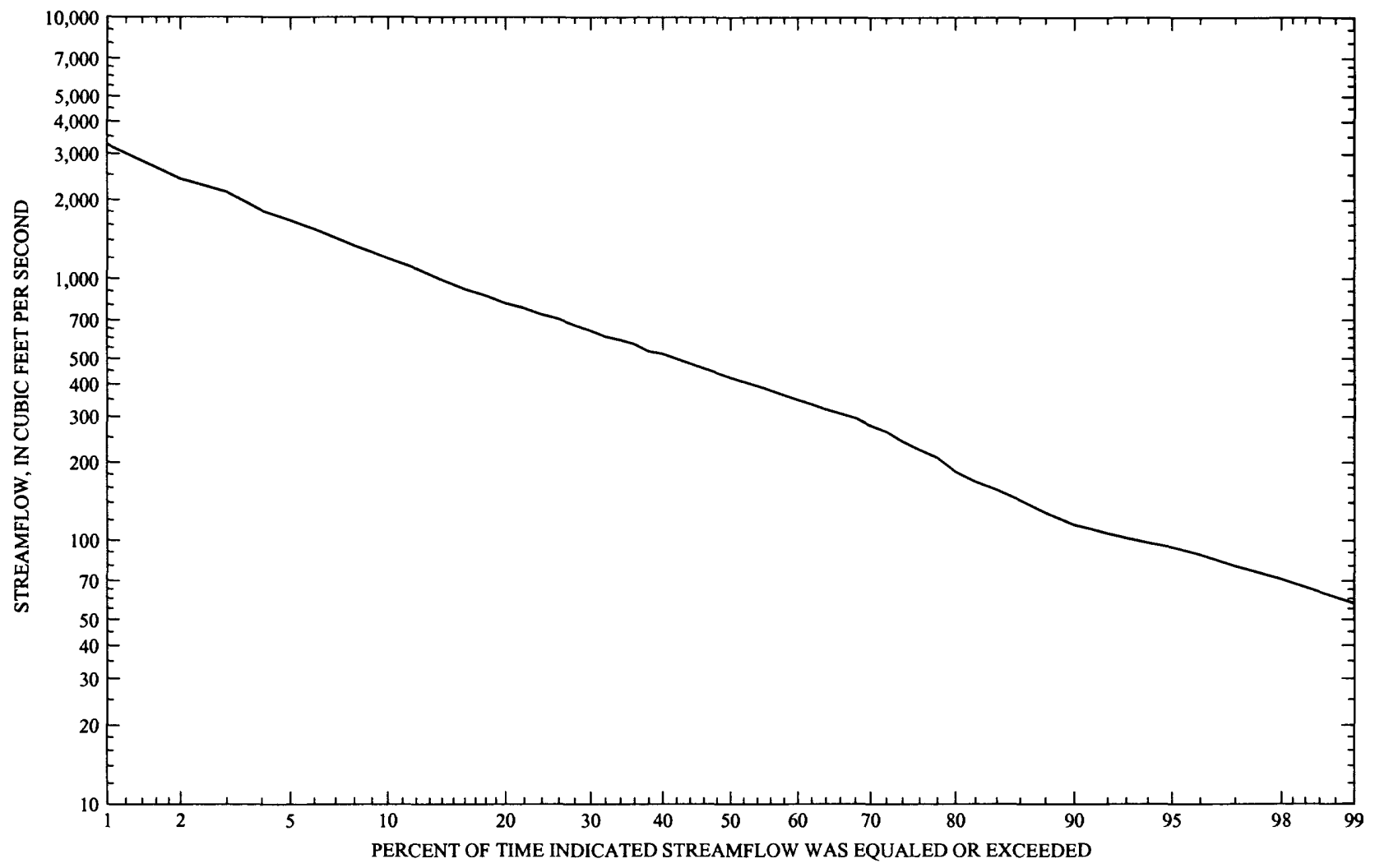

\begin{tabular}{cccc}
\hline $\begin{array}{c}\text { Percent of time } \\
\text { indicated } \\
\text { streamflow was } \\
\text { equaled or } \\
\text { exceeded }\end{array}$ & $\begin{array}{c}\text { Streamflow, in } \\
\text { cubic feet per } \\
\text { second }\end{array}$ & $\begin{array}{c}\text { Percent of time } \\
\text { indicated } \\
\text { streamflow was } \\
\text { equaled or } \\
\text { exceeded }\end{array}$ & $\begin{array}{c}\text { Streamflow, in } \\
\text { cubic feet per } \\
\text { second }\end{array}$ \\
\hline 1 & 3250 & 55 & 386 \\
5 & 1660 & 60 & 347 \\
10 & 1190 & 65 & 314 \\
15 & 950 & 70 & 278 \\
20 & 808 & 75 & 233 \\
25 & 719 & 80 & 184 \\
30 & 637 & 85 & 150 \\
35 & 576 & 90 & 115 \\
40 & 520 & 95 & 94 \\
45 & 469 & 99 & 58 \\
50 & 422 & & \\
\hline
\end{tabular}

Figure 13. Flow-duration curve and flow-duration statistics for November based on historical period of record, March 1948 through December 1992, for Narraguagus River at Cherryfield, Maine. 


\section{December}

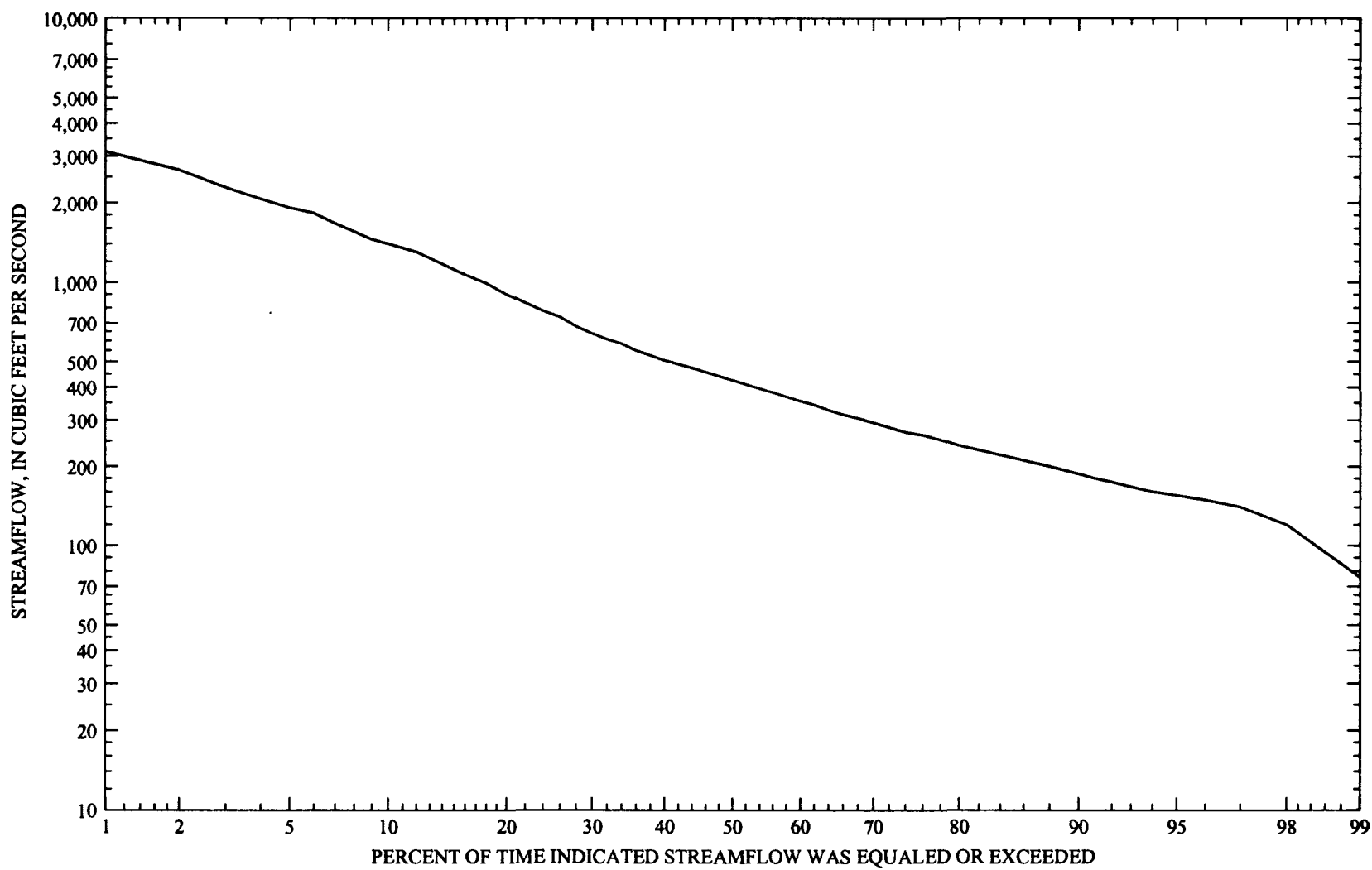

\begin{tabular}{cccc}
\hline $\begin{array}{c}\text { Percent of time } \\
\text { indicated } \\
\text { streamflow was } \\
\text { equaled or } \\
\text { exceeded }\end{array}$ & $\begin{array}{c}\text { Streamflow, in } \\
\text { cubic feet per } \\
\text { second }\end{array}$ & $\begin{array}{c}\text { Percent of time } \\
\text { indicated } \\
\text { streamflow was } \\
\text { equaled or } \\
\text { exceeded }\end{array}$ & $\begin{array}{c}\text { Streamflow, in } \\
\text { cubic feet per } \\
\text { second }\end{array}$ \\
\hline 1 & 3110 & 55 & 388 \\
5 & 1910 & 60 & 355 \\
10 & 1400 & 65 & 321 \\
15 & 1123 & 70 & 293 \\
20 & 899 & 75 & 267 \\
25 & 760 & 80 & 240 \\
30 & 640 & 85 & 215 \\
35 & 568 & 90 & 187 \\
40 & 506 & 95 & 155 \\
45 & 467 & 99 & 76 \\
50 & 426 & & \\
\hline
\end{tabular}

Figure 14. Flow-duration curve and flow-duration statistics for December based on historical period of record, March 1948 through December 1992, for Narraguagus River at Cherryfield, Maine. 


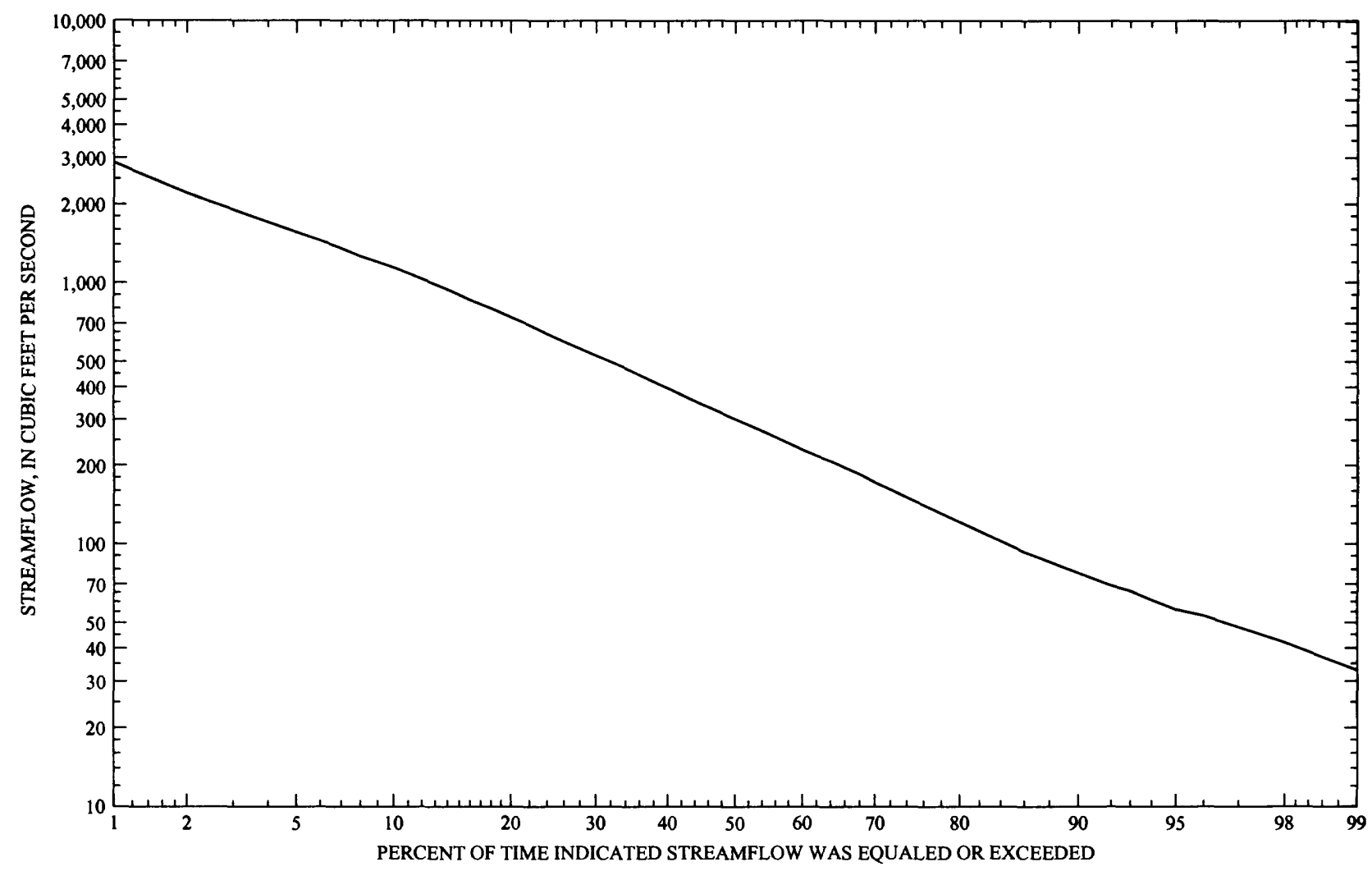

\begin{tabular}{cccc}
\hline $\begin{array}{c}\text { Percent of time } \\
\text { indicated } \\
\text { streamflow was } \\
\text { equaled or } \\
\text { exceeded }\end{array}$ & $\begin{array}{c}\text { Streamflow, in } \\
\text { cubic feet per } \\
\text { second }\end{array}$ & $\begin{array}{c}\text { Percent of time } \\
\text { indicated } \\
\text { streamflow was } \\
\text { equaled or } \\
\text { exceeded }\end{array}$ & $\begin{array}{c}\text { Streamflow, in } \\
\text { cubic feet per } \\
\text { second }\end{array}$ \\
\hline 1 & 2870 & 55 & 265 \\
5 & 1560 & 60 & 230 \\
10 & 1140 & 65 & 202 \\
15 & 899 & 70 & 172 \\
20 & 739 & 75 & 146 \\
25 & 616 & 80 & 121 \\
30 & 527 & 85 & 98 \\
35 & 456 & 90 & 77 \\
40 & 394 & 95 & 56 \\
45 & 343 & 99 & 33 \\
50 & 302 & & \\
\hline
\end{tabular}

Figure 15. Flow-duration curve and flow-duration statistics for the entire selected record, March 1948 through December 1992, for Narraguagus River near Cherryfield, Maine. 